\title{
Review
}

\section{Pteropine orthoreovirus: An important emerging virus causing infectious disease in the tropics?}

\author{
Yeh Fong Tan ${ }^{1}$, Cheong Lieng Teng ${ }^{1}$, Kaw Bing Chua², Kenny Voon ${ }^{1}$ \\ ${ }^{1}$ International Medical University, Kuala Lumpur, Malaysia \\ ${ }^{2}$ Temasek Life Sciences Laboratory, Singapore
}

\begin{abstract}
Introduction: Pteropine orthoreovirus (PRV) is an emerging zoonotic respiratory virus that has spilled over from bats to humans. Though initially found only in bats, further case studies have found viable virus in ill patients.

Methodology: PubMed was queried with the keywords of Nelson Bay orthoreovirus OR Pteropine orthoreovirus OR Melaka orthoreovirus OR Kampar orthoreovirus, and returned 17 hits.

Results: Based on prevalence studies, the presence of PRV has been reported in Malaysia and Vietnam, both developing countries. Other case reports also provide further evidence of the presence of PRV in the Southeast Asian region. Despite the absence of PRV in their home countries, travellers from Hong Kong and Japan to Indonesia have returned to their countries ill with this virus, indicating that local communities in Indonesia might be affected by this virus.

Conclusions: This work aims to bring to light this emerging zoonotic respiratory virus circulating among developing countries in Southeast Asia. To improve the understanding of PRV of the medical and scientific community in the Southeast Asian region, this work introduces the general features of PRV, reports of imported PRV, prevalence, and clinical features of PRV. Gaps in knowledge about PRV have also been identified in this work, and we hope that future studies can be undertaken to improve our understanding of this virus.
\end{abstract}

Key words: Pteropine orthoreovirus; Melaka virus; Nelson Bay virus; Kampar virus; Pulau virus.

J Infect Dev Ctries 2017; 11(3):215-219. doi:10.3855/jidc.9112

(Received 05 July 2016 - Accepted 14 November 2016)

Copyright (C) 2017 Tan et al. This is an open-access article distributed under the Creative Commons Attribution License, which permits unrestricted use, distribution, and reproduction in any medium, provided the original work is properly cited.

\section{Introduction}

Pteropine orthoreovirus (PRV) is a virus that has been isolated from bats and humans. It is of concern to the medical and scientific community in Southeast Asia, as PRV is an emerging zoonotic and respiratory virus circulating in this region. The aim of this paper is to raise awareness of the infection risk by PRV, especially in Vietnam, Malaysia, and Indonesia, as these countries has been reported in case studies to be affected by this virus.

PRV, previously known as Nelson Bay orthoreovirus (NBV), is a zoonotic virus that is found in bats but is known to infect humans. The name was changed from Nelson Bay to Pteropine (referring to fruit bats of the Pteropus spp., e.g., Pteropus poliocephalus, Pteropus hypomelanus, and Pteropus vampyrus) to reflect the reservoir hosts carrying the virus [1]. Meanwhile, the name NBV is referred to as the prototype isolate of PRV. Under the group of double-stranded ribonucleic acid (RNA) viruses, there is a family of viruses known as Reoviridae, to which PRV belongs [2]. Reovirus is also known as respiratory enteric orphan virus, since it was not known to cause any illness when it was first discovered [1]. Under Reoviridae, there are a few genera; the genus of interest in the present work is Orthoreovirus (Table 1). PRV belongs to the genus Orthoreovirus, as it shares some distinguishing common features with other orthoreoviruses: it infects only vertebrates, it is spread either through the fecal-oral route or the respiratory route, and it contains 10 double-stranded RNA segments [3].

Orthoreovirus has been found to infect a wide range of vertebrates, including humans, birds, baboons, and fruit bats [3]. Besides PRV, four other species of viruses that belong to the Orthoreovirus genus are recognized [3]. Under the species PRV, there are 12 different distinct isolates (Table 2). Most of them originated from Southeast Asia, except for NBV, which was isolated in Australia, and the Xi River virus and Cangyuan virus, which were both isolated in China. The present work describes the general features of the virus, reports of imported of PRV, prevalence data of PRV, and clinical 
Table 1. The relationship of Pteropine orthoreovirus with respect to other orthoreoviruses in the genus Orthoreovirus, family Reoviridae.

\begin{tabular}{|c|c|c|c|c|c|}
\hline Family & & & Reoviridae & & \\
\hline Genus & & & Orthoreovirus & & \\
\hline Species & $\begin{array}{c}\text { Pteropine } \\
\text { orthoreovirus }\end{array}$ & Avian orthoreovirus & Baboon orthoreovirus & $\begin{array}{l}\text { Mammalian } \\
\text { orthoreovirus }\end{array}$ & $\begin{array}{c}\text { Reptilian } \\
\text { orthoreovirus }\end{array}$ \\
\hline
\end{tabular}

features of infections due to PRV, which will facilitate understanding of PRV.

\section{General features of PRV}

Of the twelve isolates of PRV identified thus far, seven were isolated from human clinical samples, while the other five were isolated from bat samples. The bat samples includes heart blood, urine, lung specimens, intestinal specimens, and salivary swabs. In the seven isolates recovered from human samples, three cases were known to have been exposed to fruit bats, while the other four cases made no specific mention of exposure to bats, though there was history of visits to places with the potential presence of fruit bats [4-9]. With this backdrop, it appears highly likely that fruit bats (Pteropus spp. and Rousettus leschenaultia) are reservoirs and sources of PRV. It is still not known whether PRV causes illnesses in fruit bats, though some fruit bats tested positive for antibody against isolates of PRV [5].

Table 2. Pteropine orthoreovirus (PRV) isolates and their features.

\begin{tabular}{|c|c|c|c|c|c|c|}
\hline $\begin{array}{l}\text { Isolates of } \\
\text { PRV }\end{array}$ & Year & Host & Location & $\begin{array}{l}\text { Country } \\
\text { of origin }\end{array}$ & Features & Citation \\
\hline $\begin{array}{l}\text { Nelson Bay } \\
\text { orthoreovirus }\end{array}$ & 1970 & Bat & $\begin{array}{l}\text { Sydney, } \\
\text { Australia }\end{array}$ & Australia & $\begin{array}{l}\text {-Recovered from heart blood of Pteropus } \\
\text { poliocephalus } \\
\text {-Causes death and paralysis in mice }\end{array}$ & {$[15]$} \\
\hline Pulau virus & 1999 & Bat & $\begin{array}{l}\text { Tioman } \\
\text { Island, } \\
\text { Malaysia }\end{array}$ & Malaysia & $\begin{array}{l}\text {-Recovered from urine samples of Pteropus } \\
\text { hypomelanus } \\
\text {-Antibody against NBV neutralized Pulau virus }\end{array}$ & [16] \\
\hline Melaka virus & 2006 & Human & $\begin{array}{l}\text { Melaka, } \\
\text { Malaysia }\end{array}$ & Malaysia & $\begin{array}{l}\text {-Recovered from throat swab of patient suffering } \\
\text { from high fever and acute respiratory disease } \\
\text { - Two family members developed similar symptoms }\end{array}$ & [4] \\
\hline Kampar virus & 2006 & Human & $\begin{array}{l}\text { Kampar, } \\
\text { Malaysia }\end{array}$ & Malaysia & $\begin{array}{l}\text {-Recovered from throat swab of patient suffering } \\
\text { from high fever, acute respiratory disease and } \\
\text { vomiting } \\
\text {-Caused respiratory disease in contact case }\end{array}$ & {$[5]$} \\
\hline HK 23629/07 & 2007 & Human & Hong Kong & Indonesia & $\begin{array}{l}\text {-Isolated from nasopharyngeal swab of patient } \\
\text { suffering from sore throat, watery diarrhea and } \\
\text { myalgia } \\
\text {-Returned to Hong Kong after visiting Bali }\end{array}$ & {$[6]$} \\
\hline $\mathrm{Xi}$ river virus & 2010 & Bat & $\begin{array}{l}\text { Guangdong, } \\
\text { China }\end{array}$ & China & $\begin{array}{l}\text {-Isolated from lung specimens of Rousettus } \\
\text { leschenaultia near Xi River, Guangdong, China } \\
\text {-Causes syncytial cytopathic effect, shares } \\
\text { morphology and genomic pattern of PRV }\end{array}$ & {$[10]$} \\
\hline Sikamat virus & 2010 & Human & $\begin{array}{l}\text { Sikamat, } \\
\text { Malaysia }\end{array}$ & Malaysia & $\begin{array}{l}\text {-Isolated from throat swab of patient with sudden } \\
\text { onset of high fever, sore throat and myalgia } \\
\text {-No contact cases suffering from similar illness } \\
\text {-Isolated from throat and nasal swab of patient }\end{array}$ & [7] \\
\hline HK 46886/09 & 2012 & Human & Hong Kong & Indonesia & $\begin{array}{l}\text {-Traveled to Bali, Indonesia and entered bat caves } \\
\text { three days prior to illness }\end{array}$ & [8] \\
\hline HK 50842/10 & 2012 & Human & Hong Kong & Indonesia & $\begin{array}{l}\text {-Isolated from throat and nasal swab of patient } \\
\text {-History of travelling to Indonesia }\end{array}$ & {$[8]$} \\
\hline $\begin{array}{l}\text { Miyazaki-Bali } \\
2007\end{array}$ & 2014 & Human & Japan & Indonesia & $\begin{array}{l}\text {-Isolated from throat swab of patient with high } \\
\text { fever, joint pain, sore throat and cough } \\
\text {-History of travelling to Bali, Indonesia }\end{array}$ & [9] \\
\hline $\begin{array}{l}\text { Cangyuan } \\
\text { virus }\end{array}$ & 2014 & Bats & $\begin{array}{l}\text { Yunnan, } \\
\text { China }\end{array}$ & China & $\begin{array}{l}\text {-Isolated from intestinal contents of Rousettus } \\
\text { leschenaultia near Cangyuan, Yunnan, China } \\
\text {-The phylogenetic tree of S segments demonstrated } \\
\text { greater degree of heterogenity }\end{array}$ & [11] \\
\hline Indonesia/2010 & 2015 & Bats & Italy & Indonesia & $\begin{array}{l}\text {-Isolated from salivary swab of flying fox (Pteropus } \\
\text { vampyrus) originating from Indonesia } \\
\text {-Genetically similar to Melaka virus }\end{array}$ & [12] \\
\hline
\end{tabular}


PRV as an orthoreovirus is not known to have any arthropod vectors. Though there are phylogenetic associations between isolates of PRV from bats and isolates from humans, the link and mode of transmission of PRV from bats to humans are yet to be established. In cases where there was exposure to bats, it is not known if PRV was spread through respiratory droplets or fecal contents, as PRV was found in both lungs and intestinal contents of bats [4,10,11].

There are also cases of what appears to be humanto-human transmission. In the Kampar virus case, the doctor and the wife of the index patient developed antibody against PRV despite having no history of exposure to bats. They suffered a milder illness as compared to the index patient [5]. In the Sikamat virus case, though there was no evidence of direct exposure to bats, the patient periodically visited and worked in his fruit orchard. His wife had neither history of working in the fruit orchard nor history of exposure to bats or bat droppings, but was noted to have developed immunoglobulin $\mathrm{M}$ (IgM) and immunoglobulin $\mathrm{G}$ (IgG) against PRV. These findings highly support human-to-human transmission of PRV. The mode of human-to-human transmission is yet to be determined [7].

\section{Reports of imported PRV}

There were five reported incidents of imported PRV believed to originate from Indonesia (Table 2). Three cases of human disease were reported in Hong Kong and one in Japan, while the virus was detected in Italy in imported bats that did not exhibit any symptoms.

The three Hong Kong cases may have been infected with the virus in Indonesia, as all three of them had a history of travelling to Indonesia [6,8]. Further evidence supports the fact that they were imported cases, as there are no subsequent reports of detection of PRV in Hong Kong in the following years despite the surveillance program in place.

As for the Japanese case, the patient had a history of travelling to Bali, Indonesia. This prompted the authors to speculate that the patient may have been infected in Indonesia [9]. Similar to the Hong Kong case, if PRV is prevalent in Japan, one would expect more endemic cases of PRV being reported in Japan. In Italy, salivary swabs of bats imported from Indonesia were found to harbor PRV [12]. No one was reported to be infected by PRV in Italy.

\section{Prevalence study of PRV}

At the time of writing, there have been three different studies that have documented the prevalence of the virus within a human population. Two of the studies determined the prevalence of PRV through serology, while the other study used molecular detection methodology.

Chua et al. [4], who determined that $13 \%$ of the residents on an island off the east coast of peninsular Malaysia, Tioman Island, were positive for antibody against Pulau virus and Melaka virus.

Voon et al. [13] used a molecular detection method (polymerase chain reaction) and found that up to $17 \%$ of patients with upper respiratory tract infection who visited a health clinic in a suburban district in the west coast of peninsular Malaysia harbored PRV.

Singh et al. [14] used enzyme-linked immunosorbent assay (ELISA) to determine that 12 of 272 patients (4\%) studied in central Vietnam had IgG against PRV. However, it is worth noting that none of the 12 patients had IgM against PRV.

Based on the above studies, it appears that the prevalence rate of PRV in Malaysia may be higher than it is in Vietnam. The study by Voon et al. [13] had a sample size of 200 reported a PRV prevalence of $17 \%$ (34 patients), the highest ever recorded. This high prevalence might be explained by: 1) a sizeable proportion of the patients (14/34) being students living in a dormitory who they might have become infected together; 2) the target population was patients suffering from upper respiratory tract infections rather than healthy volunteers; and 3) the detection occurred during the acute phase of infection. The seroprevalence rate reported by Chua et al. [4] was lower, which might be due to the loss of immunity against PRV over time. Nonetheless, the prevalence rate between Voon et al. [13] and Chua et al. [4] is different by only 4\%. The study by Singh et al. [14] showed that the patients had been infected in the past (presence of IgG only but not IgM).

It can be said that PRV is prevalent in Southeast Asia, particularly Malaysia. There has been no prevalence study of PRV in Indonesia. Health authorities in Malaysia and Indonesia need to pay attention to the prevalence of PRV, as it might be of major health significance.

\section{Clinical features of PRV infection}

There has been no report of death due to PRV, and there is no long-term follow up study of PRV infection. Clinical features of PRV infection currently are based on published reports. Though this is less than ideal, this is probably the best information that is currently available. 
To date, PRV and Mammalian orthoreovirus (MRV) have been found to be capable of infecting humans. In patients infected by MRV, the illness that it caused has been described as mild and self-limiting [3]. Of all the cases of documented PRV infection in humans, the majority of them suffered from acute respiratory disease or influenza-like illness [4-9]. Similarly, in patients affected by PRV, the illness was self-limiting, as all documented patients eventually made an uneventful, full recovery [4,5,7-9]. Nonetheless, some patients infected by PRV developed severe illness [4]. The severe illness included high fever, followed by cough or sore throat, with some systemic symptoms such as generalized weakness and myalgia [4-9]. It is important to note that the sore throat described was severe in nature and the fever was high $[4,5,7]$.

However, it is worth noting that some patients manifested enteric symptoms such as vomiting and diarrhea [5]. One patient was noted to have abdominal pain over the epigastrium without vomiting or diarrhea [7]. PRV has been found inside the intestinal contents of fruit bats [11]. PRV may cause both respiratory and enteric illness, and requires further study to enhance our understanding of PRV.

The study by Voon et al. [13] found that cough and sore throat were the two most common symptoms associated with PRV infection. The odds ratio of having cough and PRV infection was 0.378 (95\% CI $0.148-$ 0.961 ), while the odds ratio for sore throat was 2.726 (95\% CI 1.067-6.967) [13]. This shows that patients with cough are less likely to be infected with PRV, while patients with sore throat are more likely to be infected with PRV. This is similar to the documented cases of high fever and severe sore throat $[4,5,7]$. Nonetheless, no association was established for enteric illness and PRV infection.

The incubation period of PRV is not well documented. Based on the case study of Melaka virus, approximately one week prior to developing fever, the patient was exposed to a bat that flew into his house [4]. This is the only documented case of the incubation period of PRV. Based on this case study, the incubation period of PRV infection is estimated to be approximately one week.

In some cases of PRV infection, some laboratory tests were performed to monitor the overall health status of the patients. However, there was no significant specific pattern in the laboratory results. Most laboratory results are unremarkable, with only isolated cases of elevated alanine aminotransferase and relative lymphopenia $[5,6]$ observed in the patients.
So far, no recommended specific treatment regimen had been administered to patients with PRV infection. It is fortunate that based on the documented cases of PRV infection, none of the patients suffered from any severe complication or death; all of them eventually made an uneventful, full recovery from their illness [49].

\section{Conclusions}

PRV is currently known to be a zoonotic virus that can transmit from bats to humans. From a public health point of view, communities in Southeast Asia should be cautious when dealing with bats, as they might unknowingly catch PRV and other viruses, such as Nipah virus and rabies. The medical community in Southeast Asia should monitor patients who have contact with bats, as this exposure could carry the risk of potential exposure to PRV. It is hoped that this review will raise more awareness about this virus, particularly among practicing doctors in the Southeast Asian region.

Our understanding of PRV was greatly increased by several published scientific reports; however, there are still many gaps in our knowledge of this virus. Essential information is required, such as the mode of virus transmission among fruit bats, the possible involvement of other bat species, virus spillover from bats to humans, mode of virus transmission among humans, virus virulence, and disease severity in humans. The prevalence of PRV in countries such as Indonesia, from which some cases of PRV were believed to originate, is not known either. We hope that this paper will highlight these knowledge gaps, and that future studies will be undertaken to address them.

\section{References}

1. Voon K, Chua KB, Yu M, Crameri G, Barr JA, Malik Y, Wang LF (2011) Evolutionary relationship of the L- and M-class genome segments of bat-borne fusogenic orthoreoviruses in Malaysia and Australia. J Gen Virol 92: 2930-2936.

2. Mertens P (2004) The dsRNA viruses. Virus Res 101: 3-13.

3. Attoui H, Mertens PPC, Becnel J, Belaganahalli S, Bergoin M, Brussaard CP, Chappell JD, Ciarlet M, del Vas M, Dermody TS, Dormitzer PR, Duncan R, Fang Q, Graham R, Guglielmi KM, Harding RM, Hillman B, Makkay A, Marzachi C, Matthijinssens J, Milne RG, Mohd Jaafar F, Mori H, Noordeloos AA, Omura T, Patton JT, Rao S, Maan M, Stoltz D, Suzuki N, Upadhyaya NM, Wei C, Zhou H (2012) Virus taxonomy: classification and nomenclature of viruses, Ninth Report of the International Committee on Taxonomy of Viruses. Oxford: Elsevier/Academic Press 541 p.

4. Chua KB, Crameri G, Hyatt A, Yu M, Tompang MR, Rosli J, McEachern J, Crameri S, Kumarasamy V, Eaton BT, Wang LF (2007) A previously unknown reovirus of bat origin is associated with an acute respiratory disease in humans. Proc Natl Acad Sci 104: 1-6. 
5. Chua KB, Voon K, Crameri G, Tan HS, Rosli J, McEachern J, Suluraju S, Yu M, Wang LF (2008) Identification and characterization of a new orthoreovirus from patients with acute respiratory infections. PLoS One 3: e3803.

6. Cheng P, Lau CS, Lai A, Ho E, Leung P, Chan F, Wong A, Lim W (2009) A novel reovirus isolated form patient with acute respiratory disease. J Clin Virol 1657.

7. Chua KB, Voon K, Yu M, Keniscope C, Abdul Rasid K, Wang LF (2011) Investigation of a potential zoonotic transmission of orthoreovirus associated with acute influenza-like illness in an adult patient. PLoS One 6: e25434.

8. Wong AH, Cheng PKC, Lai MYY, Leung PCK, Wong KKY, Lee WY, Lim WWL (2012) Virulence potential of fusogenic orthoreoviruses. Emerg Infect Dis 18: 944-948.

9. Yamanaka A, Iwakiri A, Yoshikawa T, Sakai K, Singh H, Himeji D, Kikuchi I, Ueda A, Yamamoto S, Miura M, Shioyama Y, Kawano K, Nagaishi T, Saito M, Minomo M, Iwamoto N, Hidaka Y, Sohma H, Kobayashi T, Kanai Y, Kawagishi T, Nagata N, Fukushi S, Mizutani T, Tani H, Taniguchi S, Fukuma A, Shimojima M, Kurane I, Kageyama T, Odagiri T, Saijo M, Morikawa S (2014) Imported case of acute respiratory tract infection associated with a member of species Nelson Bay orthoreovirus. PLoS One 9: e92777.

10. Du L, Lu Z, Fan Y, Meng K, Jiang Y, Zhu Y, Wang S, Gu W, Zou X, Tu C (2010) Xi River virus, a new bat reovirus isolated in southern China. Arch Virol 155: 1295-1299.

11. Hu T, Qiu W, He B, Zhang Y, Yu J, Liang X, Zhang W, Chen G, Zhang Y, Wang Y, Zheng Y, Feng Z, Hu Y, Zhou W, Tu C, Fan Q, Zhang F (2014) Characterization of a novel orthoreovirus isolated from fruit bat, China. BMC Microbiol 14: 293.
12. Lorusso A, Teodori L, Leone A, Marcacci M, Mangone I, Orsini M, Capobianco-Dondona A, Camma' C, Monaco F, Savini G (2015) A new member of the Pteropine Orthoreovirus species isolated from fruit bats imported to Italy. Infect Genet Evol 30: 55-58.

13. Voon K, Tan YF, Leong PP, Teng CL, Gunnasekaran R, Ujang K, Chua KB, Wang LF (2015) Pteropine orthoreovirus infection among out-patients with acute upper respiratory tract infection in Malaysia. J Med Virol 87: 2149-2153.

14. Singh H, Shimojima M, Thanh $\mathrm{CN}$, Nguyen VQH, Tran XC, An LV, Masayuki S, Ming Y, Masami S (2015) Serological evidence of human infection with pteropine orthoreovirus in Central Vietnam. J Med Virol 87: 2145-2148.

15. Gard G, Compans RW (1970) Structure and cytopathic effects of Nelson Bay virus. Am Soc Microbiol 6: 100-106.

16. Pritchard LI, Chua KB, Cummins D, Hyatt A, Crameri G, Eaton B, Wang LF (2005) Pulau virus; a new member of the Nelson Bay orthoreovirus species isolated from fruit bats in Malaysia. Arch Virol 151: 229-239.

\section{Corresponding author}

Kenny Voon

International Medical University

126, Jalan Jalil Perkasa 19, Bukit Jalil

57000, Kuala Lumpur, Malaysia

Phone: $+603-27317245$

Fax: +603-86567229

Email: kennyvgl@yahoo.com

Conflict of interests: No conflict of interests is declared. 